\title{
THE ROLE OF CULTURAL VALUE ORIENTATION IN INCREASING PRODUCTIVITY OF CREATIVE INDUSTRY IN DENPASAR CITY
}

\author{
Made Agung I D.*, Doctoral Candidate \\ Made Suyana Utama I, Nyoman Saskara Ida Ayu, Professors \\ Nym Mahaendra Yasa I, Lecturer \\ Faculty of Economics and Business, University of Udayana, Denpasar, Bali, Indonesia \\ ${ }^{\star}$ E-mail: saskara@unud.ac.id
}

\begin{abstract}
As a multicultural city, Denpasar City that has limitations in the provision of land to develop the manufacturing industry as it is done by big cities in Pula Java, does not mean it does not have the potential to develop the industry. The type of industry that is allegedly suitable to be built and developed in Denpasar City is the creative industries. Cultural orientation should be active, very important in development, especially the soul of the creativity of businessmen. Residents of Denpasar in terms of dealing with this life as a challenge to be faced actively, not only "resigned" to the fate that befalls someone, but people must actively try to change the circumstances he suffered. Is then the orientation of the cultural values of Denpasar people have an influence on the efforts to strengthen the realization of individual creativity in improving productivity to further improve the welfare. In consideration of the above, the problem in this research is: How is the influence of cultural value orientation in strengthening creativity to increase the productivity of creative industry in Denpasar City? Samples of 214 creative industries derived from 3.251 Creative industry units in Denpasar City. Analyzed using multiple regression with variable orientation of cultural value as a moderate. Gained the result that cultural value orientation plays an important role in strengthening creativity factor to improve productivity in the creative industry in the city of Denpasar which later comes down to the increase of the community welfare creative industry.
\end{abstract}

\section{KEY WORDS}

Creative industries, creativity, cultural value orientation, public service.

Cultural orientation should be active, very important in development, especially the soul of the creativity of businessmen. People in terms of dealing with this life as a challenge to be actively faced. Not only is the "resigned" of the fate that befalls a person, but one has to actively try to change the circumstances he experiences. Denpasar City is an area with the highest foreign cultural intrusion in Bali. It is not detached from the position of Denpasar, as the provincial capital, is a city in Bali with the highest transactional (economic, political, and other) intensity. In addition, together with the Badung Regency, Gianyar Regency, and Tabanan Regency; Denpasar is the center of Bali's tourism activities.

Denpasar City with the beach Sanur is a favorite tourist destination for local people, tourists and foreign tourists who want to see Sanur beach with the beauty of the sun. Sanur is a favorite tourist destination for European travelers, especially those from the Netherlands, England, and France. As one of the economic drivers of Denpasar City, tourism provides positive benefits for job growth and incubation of tourism entrepreneurial. In addition to these positive benefits, tourism as a multidimensional industry also has a negative impact. One of them is the outside cultural intrusion that brought tourists to local people culture.

The influence of indirect negative by tourism in the city of Denpasar, is observed in the urbanization of residents of other districts in the province of Bali and neighboring provinces. Denpasar City as the provincial capital and tourism activities that stand out leads to the rate of economic growth always above the rate of economy growth of Bali province. This condition caused Denpasar city to serve as the center of Economic growth of Bali, which has an increase in the number of migrants, especially non-Balinese, to work and strive in the city of Denpasar. 
The increasing number of foreign tourists who visit Bali as well as the growing number of non-Balinese population in Denpasar, are two conditions that cause the transaction of non-Balinese cultural values with Balinese culture and vice versa become increasingly intensive. The city of Denpasar, slowly transformed from the city with a ' face ' culture into a multicultural city. Along with the increasing frequency of interactions among individuals who have different cultures, it will be increasingly open to the transformation of norms and values of society caused by the process of cultural acculturation (Koentjaraningrat, 2005; Hofstede et al., 2010), a local culture (Bali) with non-Balinese culture, including Western culture.

As a multicultural city, Denpasar City that has limitations in the provision of land to develop the manufacturing industry as it is done by big cities in Java island, does not mean it does not have the potential to build the industry. The type of industry that is allegedly suitable to be built and developed in Denpasar City is the creative industries consider: 1) The open attitude and friendliness of the people of Denpasar in particular and the Balinese community in general to foreign citizens and Indonesian citizens of ethnic or ethnic groups, showed that the residents ' tolerance of Denpasar city can be used as capital to build creative industry; 2) The art of tradition and cultural assets are well preserved. Related to traditional artifacts (arts, handicraft products, and others), they can easily be found talented individuals in their respective forms of artifact. Talent is the second capital to build the city of Denpasar as a creative city, and; 3 ) As the provincial capital, the city of Denpasar has stood a number of educational institutions (medium and high) which are capable of producing technology to support the creativity of its inhabitants.

Community tolerance and talents from the people of Denpasar City, making Denpasar and Bali generally a meeting point of various ethnic world who do not just want to enjoy the beauty of nature, but also want to work and collaborate with other ethnic citizens. Such interactions are an important factor for the economy of the Balinese community and make Bali increasingly famous as a work place for many world-class creative individuals (Indonesia Design Power Working Group, Ministry of Trade RI, 2008). Moelyono (2010) it is mentioned that the most prominent characteristics of the creative industry that tend to be different from the industry in general is because the input is largely intangible, namely individual ideas and creativity.

Table 1 - The Number of Creative Industries in Denpasar City in 2017

\begin{tabular}{|c|l|c|c|}
\hline No & \multicolumn{1}{|c|}{ Description } & Amount & Information \\
\hline 1 & The advertising field & 241 & Unit \\
\hline 2 & Architecture & 76 & Unit \\
\hline 3 & Art goods market & 1 & Unit \\
\hline 4 & Craft field & 616 & Unit \\
\hline 5 & Field of Design & 163 & Unit \\
\hline 6 & Fashion sector & 5 & Unit \\
\hline 7 & Video, Film, Photography & 393 & Unit \\
\hline 8 & Interactive Game & 1 & Unit \\
\hline 9 & Music Field & 61 & Unit \\
\hline 10 & Performing Arts & 171 & Studio \\
\hline 11 & Publishing and Printing & 886 & Unit \\
\hline 12 & Computer Software Services & 614 & Studio \\
\hline 13 & Television and Radio & 22 & campus \\
\hline 14 & Research and development & 1 & Total \\
\hline
\end{tabular}

Source: Denpasar City Central Statistics Agency (2018).

In table 1 above, there are a total of 3251 creative industries, based on the creative industry sectors, the 14 sectors seem to be all or some who enter the industry in general. As an example tourism industry almost the entire sector went there. Starting from the architecture by looking at the form of hotel buildings and villas, in terms of design, how branding, promotion to tourism through publishing and printing is necessary to support this industry. To impact the quality of life of the community in general is required creativity to 
accomplish it and it is also thrust with the productivity of the community itself. According to Sedarmayanti (2009), the advantages or benefits of increased productivity will cause: a) increased income and other social security, it will enlarge the ability (power) to buy goods and services or necessities of life every day, so that welfare will be better. From the other side, the increase in revenue can be saved which will be beneficial for investment; $b$ ) increased desire and dignity and recognition of individual potential; c) increase motivation for work and achievement.

In supporting the creativity of the people of Denpasar, Technology, Tolerance, and Talent (3T) from Richard L. Florida applied, and still consider the orientation of the cultural values of the people of Denpasar, so efforts to strengthen the realization of individual creativity to increase productivity that can further improve the welfare. In consideration of the above, the problem in this research is: How is the influence of cultural value orientation in strengthening creativity to increase the productivity of creative industry in Denpasar City?

Creativity is the economy's 'mobilizer'. Explicitly, Florida even mentions "This economy is powered not by information or by knowledge, but by Human creativity". Creativity is a multidimensional concept. According to Florida (2002), there are three forms of creativity: (a) technological creativity, (b) Economic creativity, and (c) artistic/cultural creativity. Technological creativity is a form of creation that leads to new findings (inventions); economic creativity is more reflected in the formation of individuals who have entrepreneurial spirit; and artistic/cultural creativity that stems from the building of art and or cultural products. These three forms of creativity are related to one another in the form of interactions between technology, art, and business that will bring out the realm of the new economy, known as the creative industry.

A formal definition of creativity that is widely referenced in scientific writings is the definition of the UK Department of Trade and Industry that expresses creativity "as the production of new ideas that are fit for particular business purpose" (DTI, 2005). This definition strictly frames creativity as a process of generating new, economically beneficial ideas:

1) Orientation: The stage of orientation is an early stage in creative thinking. In the orientation stage, one will try to examine and formulate the problem he faced; Devise alternative solutions that can be chosen; and choose or establish an approach that will be used to determine one of the alternatives to the problem faced by;

2) Preparation: The preparation stage is the stage of collecting facts, information, and other supporting materials relevant to the activity of the person in the previous stage;

3) Analysis: The stage of analysis is related to processing activities and analyzing all materials collected at the preparation stage aimed at choosing the best alternative to the problems identified in the orientation stage;

4) Synthesis: The fourth stage of the series of creative thinking stages is aimed at testing out the best alternatives that have been determined in the previous stage;

5) Incubation: The last stage of a series of creative thinking stages is characterized by the possibility of a person 'forgetting' the problem he faced and ' seeing ' the opportunity that benefits him with solutions or alternative solutions that are designed in relation to the initial problems he faced.

The fifth set of stages above often does not run linear. Sometimes someone returns to the previous step, after proceeding to the next stage, when he realizes there is confusion in the previous stages. The stage of creative thinking is the un-ending stages of creative thinking.

According to Winardi (2003), there are several traits of thinking and creative individuals, namely: always try to present original ideas or ideas by creating new interconnectedness between things he has been aware of; Have a habit of paying attention to the less or unexpected things surrounding it; It has an expanse of thinking and spontaneity in thinking, as well as; Have a willingness to work hard in realizing his ideas. The creativity of a person is not static, various studies show that creativity can be improved and developed through a number of trainings. Although one's ability and talent is a fundamental capital for his creativity, knowledge from his environment is proven to increase one's creativity. Through 
the four traits of previous creative thinking, one's creativity can be improved. Although it has been successfully identified as creative individuals, the cause of a person to be more creative than other people is still a very interesting researcher, especially in the realm of psychology.

One of the perspectives on the cause of creativity is diversity. Florida (2002) argues that a person's creativity will emerge (pop-out) when his environment allows an intensive interaction between individuals who have a different lifestyle, ethnicity, and culture. So, those areas that wish to build the creative class of the group of inhabitants must be able to build the diversity. The creation of a creative part of the population will encourage the growing creative economy, which will then attract the interest of creative individuals from outside the region to live in it.

The Focus Group Discussion (FGD) and its interviews on creative young people in the United States, in having a residential and workplace location, confirm that the territorial diversity of ethnic, cultural, and lifestyle perspectives is the most important factor posed by the respondents.

As it says, the most important question associated with the phenomenon of collecting similar industries in a regional cluster is why it happens. Moving on from human resource theory that believes that significant economic growth will be observed in areas whose population has quality (from the education side) adequate, there are three main reasons for collecting talented individuals, having creativity, and having an entrepreneurial spirit; In certain areas:

1) Labour market: people not only need a job choice available to him but a number of job options. Creative and talented individuals need a thick labor market;

2) Diversity: Creative individuals need a clear signal about cultural, lifestyle, and ethnic diversity in a region of territory. The existence of this signal demonstrates the tendency of ' low entry barries ' for entrants;

3) Quality of residence: the quality of a person's residence according to Florida terminology defined in 3W namely: (a) What's there, covering buildings, neighbors, as well as designing physical architecture; (b) Who's there, covering people, diversity, and the living spirit of the inhabitants; and (c) What's going on, covering the street atmosphere, availability of roadside cafés, dining venues, music, and other outdoor activities.

Based on the synthesis above, Florida believes that economic growth occurring in a region is controlled by creative individuals who prefer entrant-tolerant places, open to new ideas, and have ethnic and cultural diversities. These creative individuals are actually a creative capital that differs from the human capital of the two points of view: 1) Not all human resources are capital for the economic growth of the region. Only real creative individuals are the triggers of economic growth; 2). There are factors that become a sense for the creative individuals to stay in and not just by chance or grace it happens. In addition, creativity is associated with the diversity of socio-demographic character of a region.

Although Florida was able to provide convincing examples of the correctness of the theory of economic growth based on creativity, criticism of this theory is also not less numerous. One of the critics of Florida is Ann Markunsen, professor of development Economics of the University of Minnesota, USA. In his writings, Markunsen declared Florida's idea of creative class an obscure (fuzzy) idea and almost impossible to conceptualize a class (a group) based on the same interests (common interests) (Markusen, 2006). According to the definition of creative industry, according to United Kingdom Departement, Culture, Media and Sport (DCMS, 2001) are various things that require creativity, skills, and talent that is done for the creation of employment opportunities and welfare through the exploitation of intellectual property. The activities covered include advertising, architecture, art market and antiques, handicraft, design, fashion, film and video, music, performing arts, printing, software, television and radio as well as video and computer games. Likewise according to UNCTAD (in UN, 2008), the creative industries are defined as: 1) The cycle of creation, production, and distribution of service goods that use the capital of creativity and intellectual as the primary inputs; 2) A series of knowledge-based activities that are emphasized on the art of potentially providing income from trade and rights to intellectual 
property; 3) consist of intellectual product or artistic services, both naked eye and not, with creative material, economic value, and has a clear target market; 4) The intersection between arts, services, and industrial sectors; 5) The realization of a dynamic new sector in world trade.

Increasing the productivity of an industry is needed creativity, in accordance with the development of the era and technology, information, and communication (TIC), so that everything is to follow the era and development of consumer tastes so that the industry products can be sustainable. Besides, there are several factors that affect productivity, among others: 1) ability, which is the proficiency that is owned by a person either from knowledge gained through formal education or his skills. With this ability it will be able to improve work productivity; 2) Situations and circumstances of the environment, this factor usually concerns the facilities and circumstances where all employees can work well and quietly; 3) motivation in increasing productivity, where motivation is the driving force or element of one's activities towards a particular goal and involving all the skills it has to achieve it; 4) The minimum wage or salary or that does not comply with the regulations will result in the productivity of the work of the employees declining; 5) The level of education and also training of labor will affect the productivity of one's work, where it is as an investment in the field of human resources. Where the level of education for the workforce must always be developed or improved both through formal and informal educational pathways. This is particularly important where it relates to the dynamics or changes occurring within an organizational environment; 6) Employment agreements which constitute a tool that guarantees the rights and obligations of employees; 7) Application of technology can greatly affect the productivity of work therefore the application of technology must be oriented to maintain productivity. With The technological advancement is expected to improve the productivity of the work and also facilitate the human in carrying out its duties. (Heriandja, 2002)

Another thing that is not less important is the values of local culture and is accepted by the market, which can lead to increased artistic production process (artistic producing) that impacts on the increasing welfare of the craftsmen family or artists while strengthening the conservation efforts of local cultural values (Cowen, 1998). The conservation of local cultural values because of globalization and the development of the creative industry is justified by research on the perception of local people in Kuta and Nusa Dua region, two tourism centers of Bali, regarding the impact Tourism in both areas was carried out by Kencana and Darmayanti in the year 2014. Both researchers confirm that tourism in addition to providing economic benefits to the community in both regions also provides benefits in the field of socio-cultural through the increasing efforts of local communities to further preserve and protect Hindu holy places and local wisdom values that forms artefacts have an economical value (Kencana \& Darmayanti, 2014).

In connection with the role of culture in the efforts to improve human welfare, the values of the society that dominates a community may be the central point of cultural role in the Society (Weber, 1958; Hofstede, 1980) in Schwartz (2009). These values underlying the concept of things deemed good in a community order. As a latent variable that can only be measured through its manifestations, Schwartz looks at the normative values of the culture that become the center of influence and form the coherency or discohercence of its agents. So, culture does not lie in the mind or actions that an individual does, but beyond these two things as a reaction of the various actions that are perceived as human beings in a social order system.

The proposed hypothesis was: creativity and cultural value of creative industry actors in Denpasar City directly influence positive and significant productivity. Cultural value orientation strengthens the influence of creativity in creative industry in Denpasar City.

\section{MATERIALS AND METHODS OF RESEARCH}

This research was conducted in Denpasar, by targeting households of creative industry business owners. The city of Denpasar was chosen as the research locus noticing its 
position as the capital of Bali's Province where education and business center were concentrated. In addition, Denpasar is a city that is heterogeneous population according to ethnic and cultural. The population in this research is all creative industries recorded in 2017 in Denpasar, amounting to 3.251 units. With the number of samples 214 obtained using the formula Slovin, shown in Table 2:

Table 2 - Sample distribution by industry category

\begin{tabular}{|c|c|c|c|c|}
\hline No & Description & Amount & Percentage & Number of samples \\
\hline 1 & The advertising field & 241 & $7.41 \%$ & 16 \\
\hline 2 & Architecture & 76 & $2.34 \%$ & 5 \\
\hline 3 & Art goods market & 1 & $0.03 \%$ & 0 \\
\hline 4 & Craft field & 616 & $18.95 \%$ & 41 \\
\hline 5 & Field of Design & 163 & $5.01 \%$ & 11 \\
\hline 6 & Fashion sector & 5 & $0.15 \%$ & 1 \\
\hline 7 & Video, Film, Photography & 393 & $12.09 \%$ & 26 \\
\hline 8 & Interactive Game & 1 & $0.03 \%$ & 0 \\
\hline 9 & Music Field & 61 & $1.88 \%$ & 4 \\
\hline 10 & Performing Arts & 171 & $5.26 \%$ & 11 \\
\hline 11 & Publishing and Printing & 886 & $27.25 \%$ & 57 \\
\hline 12 & Computer Software Services & 614 & $18.89 \%$ & 40 \\
\hline 13 & Television and Radio & 22 & $0.68 \%$ & 1 \\
\hline 14 & Research and development & 1 & $0.03 \%$ & 0 \\
\hline & Total & 3.251 & $100.00 \%$ & 214 \\
\hline \multicolumn{3}{|c|}{ Variable } & \multicolumn{2}{|c|}{ Type } \\
\hline \multicolumn{3}{|c|}{ Creativity $\left(\mathrm{X}_{1}\right)$} & \multicolumn{2}{|c|}{ Exogenous variables } \\
\hline \multicolumn{3}{|c|}{ Cultural value Orientation $\left(\mathrm{X}_{2}\right)$} & \multicolumn{2}{|c|}{ Exogenous variables } \\
\hline \multicolumn{3}{|c|}{ Productivity $(\mathrm{Y})$} & \multicolumn{2}{|c|}{ Endogenous variables } \\
\hline
\end{tabular}

Table 3 - Operational Definitions Creativity Variable $\left(X_{1}\right)$

\begin{tabular}{|c|c|c|}
\hline Dimensions/Indicators & Items & Reference \\
\hline \multirow{3}{*}{$\begin{array}{l}\text { Fluency } \\
\qquad\left(\mathrm{X}_{1.1}\right)\end{array}$} & Number of ideas expressed as a solution to the problem & \multirow{2}{*}{ Munandar (1999) } \\
\hline & Have a high imagination & \\
\hline & Frequency to propose initiatives & Torrance (1986) \\
\hline \multirow{3}{*}{$\begin{array}{l}\text { Flexibility } \\
\left(\mathrm{X}_{1.2}\right)\end{array}$} & The frequency of asking good questions & \multirow{2}{*}{ Munandar (1999) } \\
\hline & Able to work independently & \\
\hline & Have the ability to tolerate the uncertainty of results & Sternberg (1990) \\
\hline \multirow{3}{*}{$\begin{array}{l}\text { Originality } \\
\qquad\left(\mathrm{X}_{1.3}\right)\end{array}$} & A great boost of curiosity & \multirow{3}{*}{ Munandar (1999) } \\
\hline & Freedom to argue & \\
\hline & Originality thinking & \\
\hline \multirow{3}{*}{$\begin{array}{l}\text { Elaboration } \\
\qquad\left(\mathrm{X}_{1.4}\right)\end{array}$} & Prominent in one of the areas of art & \multirow{3}{*}{ Munandar (1999) } \\
\hline & Humorous & \\
\hline & Capable of elaborating ideas & \\
\hline \multirow{3}{*}{$\begin{array}{l}\text { Redefinition } \\
\qquad\left(X_{1.5}\right)\end{array}$} & Has high sensitivity on beauty & \multirow{3}{*}{ Munandar (1999) } \\
\hline & Not easily influenced by others & \\
\hline & Happy experimenting & \\
\hline
\end{tabular}

As a latent variable, the orientation of a person's cultural values will be operationalized following the dimensions suggested by Shalom H. Schwartz (2012), as follows.

Table 4 - Operational definitions for cultural value orientation variables $\left(\mathrm{X}_{2}\right)$

\begin{tabular}{|c|c|c|}
\hline Dimensions/Indicators & Items & Reference \\
\hline \multirow{3}{*}{$\begin{array}{l}\text { Intellectual autonomy } \\
\left(\mathrm{X}_{2.1}\right)\end{array}$} & Broadmindedness & \multirow{5}{*}{$\begin{array}{l}\text { (Schwartz, 2012) } \\
\text { (Lebedeva et al., 2013) } \\
\text { (Koentjaraningrat, 2005) }\end{array}$} \\
\hline & Curiosity & \\
\hline & The view on creativity done by both himself and others & \\
\hline \multirow{2}{*}{$\begin{array}{l}\text { Affective autonomy } \\
\left(\mathrm{X}_{2.2}\right)\end{array}$} & The intensity of use of innovative products or services in his personal life & \\
\hline & The intensity of use of innovative products or services in family life & \\
\hline \multirow{3}{*}{$\begin{array}{l}\text { Embeddedness } \\
\left(\mathrm{X}_{2.3}\right)\end{array}$} & Respect for the values of cultural traditions & \multirow{3}{*}{$\begin{array}{l}\text { (Schwartz, 2012) } \\
\text { (Lebedeva et al., 2013) } \\
\text { (Koentjaraningrat, 2005) }\end{array}$} \\
\hline & Adherence to cultural values & \\
\hline & Perception of the advancement of Science and its position in cultural development & \\
\hline \multirow{3}{*}{$\begin{array}{l}\text { Egalitarianism } \\
\left(\mathrm{X}_{2.4}\right)\end{array}$} & Perception of human similarity (equality) and social justice & \multirow{5}{*}{$\begin{array}{l}\text { (Schwartz, 2012) } \\
\text { (Lebedeva et al., 2013) } \\
\text { (Koentjaraningrat, 2005) }\end{array}$} \\
\hline & Perception of his role as an individual in the social system & \\
\hline & Attitude about Honesty & \\
\hline \multirow{2}{*}{$\begin{array}{l}\text { Authority } \\
\left(\mathrm{X}_{2.5}\right)\end{array}$} & Perception of hierarchy on social systems & \\
\hline & Perception of welfare should be for all strata of society & \\
\hline \multirow{3}{*}{$\begin{array}{l}\text { Harmony } \\
\left(\mathrm{X}_{2.6}\right)\end{array}$} & Perceptions of life harmony with the environment & \multirow{5}{*}{$\begin{array}{l}\text { (Schwartz, 2012) } \\
\text { (Lebedeva et al., 2013) } \\
\text { (Koentjaraningrat, 2005) }\end{array}$} \\
\hline & Respect for others & \\
\hline & Respect for the environment & \\
\hline \multirow{2}{*}{$\begin{array}{l}\text { Mastery } \\
\left(\mathrm{X}_{2.7}\right)\end{array}$} & Ambition or ideals in his life & \\
\hline & Self-sufficiency & \\
\hline
\end{tabular}


In this study individual productivity was operationalized following the dimensions suggested by Hariandja (2012), as follows:

Table 5 - Operational definitions for productivity variables $(\mathrm{Y})$

\begin{tabular}{|c|l|}
\hline Dimensions/Indicators & \multicolumn{1}{|c|}{ Items } \\
\hline \multirow{2}{*}{ Ability $\left(\mathrm{Y}_{1}\right)$} & Reference \\
\cline { 2 - 2 } & Understand the power of personal self in the business \\
\hline \multirow{2}{*}{ Environmental situation and circumstances $\left(\mathrm{Y}_{2}\right)$} & Understanding the opportunities of the business \\
\cline { 2 - 2 } & Understand the threat to the effort \\
\hline \multirow{2}{*}{ Motivation $\left(\mathrm{Y}_{3}\right)$} & Desire to develop the market \\
\cline { 2 - 2 } & Desire to develop relationships with customers \\
\hline \multirow{2}{*}{ Level of Education $\left(\mathrm{Y}_{4}\right)$} & Formal education related to the effort \\
\cline { 2 - 2 } & Knowledge related to the effort \\
\hline \multirow{2}{*}{ Technology $\left(\mathrm{Y}_{5}\right)$} & Vision on the use of technology on product innovations \\
\cline { 2 - 2 } & Vision on the use of technology in process innovations \\
\hline
\end{tabular}

The Data collected in this study through observations, questionnaire and interviews, where interviews were needed to be more in-depth and could also be asked for opinions or ideas that could not be obtained from the questionnaire method. And the data is then analyzed using multiple regression models where the cultural value orientation $\left(X_{2}\right)$ variable is as a moderation variable in the relationship between the variable creativity $\left(X_{1}\right)$ and the productivity variable $(\mathrm{Y})$. With the following models:

$$
Y=\beta_{0}+\beta_{1} X_{1}+\beta_{2} X_{2}+\beta_{3} X_{1} X_{2}+\varepsilon
$$

\section{RESULTS AND DISCUSSION}

The results above show that the variable creativity significantly affects productivity, as well as a variable of cultural value orientation to productivity., where the role of cultural value orientation as moderation strengthening the influence of creativity on productivity. Which means the role of an Intellectual autonomy indicator, Affective autonomy, Embeddedness, Egalitarianism, Authority, Harmony, and Mastery is to play an important role that how the expanse of sight to new things, the curious and the view of creativity can affect one's creativity to increase productivity. Coupled with respect and adherence to cultural values as local wisdom will strengthen the creative industry in the city of Denpasar, to have the competitiveness of the market both national and international.

Table 6 - Model Summary

\begin{tabular}{|c|c|c|c|c|}
\hline Model & $\mathrm{R}$ & $\mathrm{R}$ Square & Adjusted R Square & Std. Error of the Estimate \\
\hline 1 & $.629^{\mathrm{a}}$ & .396 & .388 & .71219159 \\
\hline
\end{tabular}

a. Predictors: (Constant), X1X2, X1, X2.

Coefficients $^{\mathrm{a}}$

\begin{tabular}{|c|c|c|c|c|c|c|}
\hline \multirow{2}{*}{\multicolumn{2}{|c|}{ Model }} & \multicolumn{2}{|c|}{ Unstandardized Coefficients } & \multirow{2}{*}{$\begin{array}{c}\begin{array}{c}\text { Standardized } \\
\text { Coefficients }\end{array} \\
\text { Beta } \\
\end{array}$} & \multirow[b]{2}{*}{$\mathrm{t}$} & \multirow[b]{2}{*}{ Sig. } \\
\hline & & B & Std. Error & & & \\
\hline \multirow[t]{4}{*}{1} & (Constant) & -.036 & .055 & & -.661 & .510 \\
\hline & $\mathrm{x} 1$ & .182 & .056 & .203 & 3.235 & .001 \\
\hline & $\mathrm{x} 2$ & .532 & .066 & .532 & 8.068 & .000 \\
\hline & $\times 1 \times 2$ & .115 & .056 & .124 & 2.055 & .041 \\
\hline
\end{tabular}

a. Dependent Variable: $Y$

Table 7 - Influence between variables

\begin{tabular}{|c|c|c|c|}
\hline Influence between variables & Regression Coefficient & T Statistics & P Values \\
\hline Creativity $\rightarrow$ Productivity $(\mathrm{X} 1 \rightarrow \mathrm{Y})$ & 0,182 & 3,235 & 0,001 \\
\hline Cultural Value Orientation $\rightarrow$ Productivity $(\mathrm{X} 2 \rightarrow \mathrm{Y})$ & 0,532 & 8,068 & 0,000 \\
\hline $\mathrm{X} 1 \mathrm{X} 2 \rightarrow \mathrm{Y}$ & 0,115 & 2,055 & 0,041 \\
\hline
\end{tabular}

Source: Analysis results. 
The fact of construction of Denpasar City has realized various development programs, both physical and non-physical. Implementation of the development has encouraged the development of creative industries so Denpasar City lead to become creative city. Concrete development, both in micro level and macro growing creatively. Based on several research results that the discussion on the breadth of work productivity gap between European countries Synthesized in addition to the capital factors (production), social capital, and economic agglomeration (Maroto and Cuadrado-Roura, 2011), allegedly emerging new causes, namely one of them is creativity. Creativity is termed brain power intangibles by Boix-Domenech \& Soler-Marco (2017). Similarly, the research results of Diana et al. (2017) which examines the role and development of the creative industry in supporting tourism in the village of Mas and Peliatan-Ubud village, found that one of the strengths in the development of Handycraft as a form of creative industry is the presence of creative and innovative human resources. Two of the results of the study showed that the creativity do play an important role in increasing the productivity of the creative industry, let alone strengthened by respect and adherence to cultural values that exist.

This is in accordance with the research results of Maroto and Cuadrado-Roura (2011), that one of the new factors impacting the productivity gap is cultural value. The orientation of cultural values is also referred to as brain power intangibles by Boix-Domenech \& SolerMarco (2017). In addition, research into the cultural value orientation variation is also intended to get an overview of the cultural value system of ethnic groups, and to explore the community that has a suitable cultural value orientation system and support the implementation of national development. As the justifications of the influence of cultural orientation values on individual productivity, Chudnovsky et al research results (2006) that innovation as a manifestation of the orientation of cultural values is believed to be an opportunity to increase productivity. This research was conducted on household and small manufacturing companies in Argentina with the results that the classification of products/services produced is unique compared to products/services that have been available in the market, or produced using radical process technology. Using Tobit regression, they also gained evidence that the company's innovation as one form of the orientation of its cultural values enhances business productivity.

The conclusion that can be conveyed that the creativity and cultural value orientation is directly to affect the productivity of the creative industry in Denpasar, and the orientation of cultural value is strengthening the relationship between creativity with the productivity of the creative industry in the city of Denpasar.

\section{REFERENCES}

1. Boix-Domenech, Rafael \& Soler-Marco, Vicent (2015), Creative service industries and regional productivity, Paper in Regional Science, Volume 96, issue 2.

2. Cowen, T., 1998. In Praise of Commercial Culture. Cambridge, MA: Harvard University Press.

3. Chudnovsky D, A Lopes, Pupato G, 2006, Innovation and Productivity in Developing Countries: A Study of Argentine manufacturing firms' behavior (1992-2001), Volume 35, Issue 2,

4. DCMS, 2001. Creative Industries Mapping Document 2001. London: UK Government Department for Culture, Media and Sport.

5. Diana, P., Suwena, I K., and Wijaya, N.M.S. 2017. Role and development of creative industry in supporting tourism in Desa Mas and Peliatan village, Ubud. Journal of Tourism Analysis, Vol.17, No.1, 84-92.

6. DTI, 2005. Creativity, Design and Business Performance. Economic Paper No. 15. London: Department of Trade and Industry, UK.

7. Florida, R.L., 2002. The Rise of the Creative Class: And how It's Transforming Work, Leisure, Community and Everyday Life. Reprint ed. Basic Books.

8. Hariandja, Marihot Tua Efendi, 2002, Human Resource Management, Grasindo, Jakarta 
9. Hofstede, G., Hofstede, G.J. \& Minkov, M., 2010. Cultures and Organizations: Software of the Mind. 3rd ed. London: McGraw-Hill.

10. Kencana, E.N. \& Darmayanti, T., 2014. Will Tourism in Bali Sustain? Study of Community's Perception towards Tourism at Kuta and Nusa Dua Areas. In Open Fortress: Sustainable of Bali Tourism. Denpasar, Bali, 2014.

11. Koentjaraningrat, 2005. Cultural mentality and development. Jakarta: Gramedia Pustaka Utama.

12. Markusen, A., 2006. Urban Development and the Politics of a Creative Class: Evidence from the Study of Artists. Environtment and Planning A, 38(10), pp.1921-40.

13. Maroto Sánchez Andres And Cuadrado Roura Juan Ramón, 2011 Analyzing The Role of Service Sector on Productivity Growth Across European Regions.

14. Minister of trade of the republic of Indonesia, 2008, Study of Indonesia's Creative Industry.

15. Moelyono, Muled, 2010, Moving the creative economy between demands and needs, ACEH: Raja Grafindo Persada.

16. Munandar, U., 1999. Creativity and Sustainability: strategy to realize creative potential and talent. Jakarta: Gramedia Pustaka Utama.

17. Schwartz, S.H., 2009. Cultural Value Orientations: Nature \& Implications of National Differences. Research Paper. Jerusalem: Israel Science Foundation the Hebrew University of Jerusalem.

18. Schwartz, S.H., 2012. An Overview of the Schwartz Theory of Basic Values. Online Readings in Psychology and Culture, 2(1), pp.1-20.

19. Sedarmayanti.2009. Human Resources and Productivity Work. Bandung: CV Mandar Maju.

20. Sternberg, R. J. (2000). Creativity is a decision. In A. L. Costa (Ed.), Teaching for intelligence II (pp. 85-106). Arlington Heights, IL: Skylight Training and Publishing.

21. UNCTAD (2008). "Creative Economy Report, 2008".

22. Torrance, Paul, E,H. Tammy Safter, 1986, Are Children Becoming More Creative?

23. Winardi, 2003. Entrepreneur and Entrepreneurship. Jakarta: Prenada Media. 